\title{
Feathers fly over Hawaiian bird
}

High on a Hawaiian mountain, scientists and wildlife managers are clashing over how best to save an endangered bird. The dispute is halting research, blocking student projects and potentially undermining conservation plans for a rainforest that cloaks part of the Big Island of Hawaii.

A team led by ornithologist Leonard Freed of the University of Hawaii at Manoa says that competition with an invasive species the Japanese white-eye (Zosterops japonicus) - has caused a population crash among a honeycreeper called the Hawaii 乔 akepa (Loxops coccineus). But

$\stackrel{a}{\circ}$ the officials who manage the 13,000-hectare Hakalau Forest National Wildlife Refuge, in which the birds live, say they see no long-term decline in numbers. Freed fears that his research is being ignored as the refuge is completing its comprehensive conservation plan.

Freed, who often works with his wife and University of Hawaii colleague Rebecca Cann, has clashed for years with John Jeffrey, the refuge's wildlife biologist, who is a noted wildlife photographer. The infighting is "the worst possible situation”, says Stuart Pimm, a conservation biologist at Duke University in Durham, North Carolina. If Freed is right, akepa populations could continue to decline
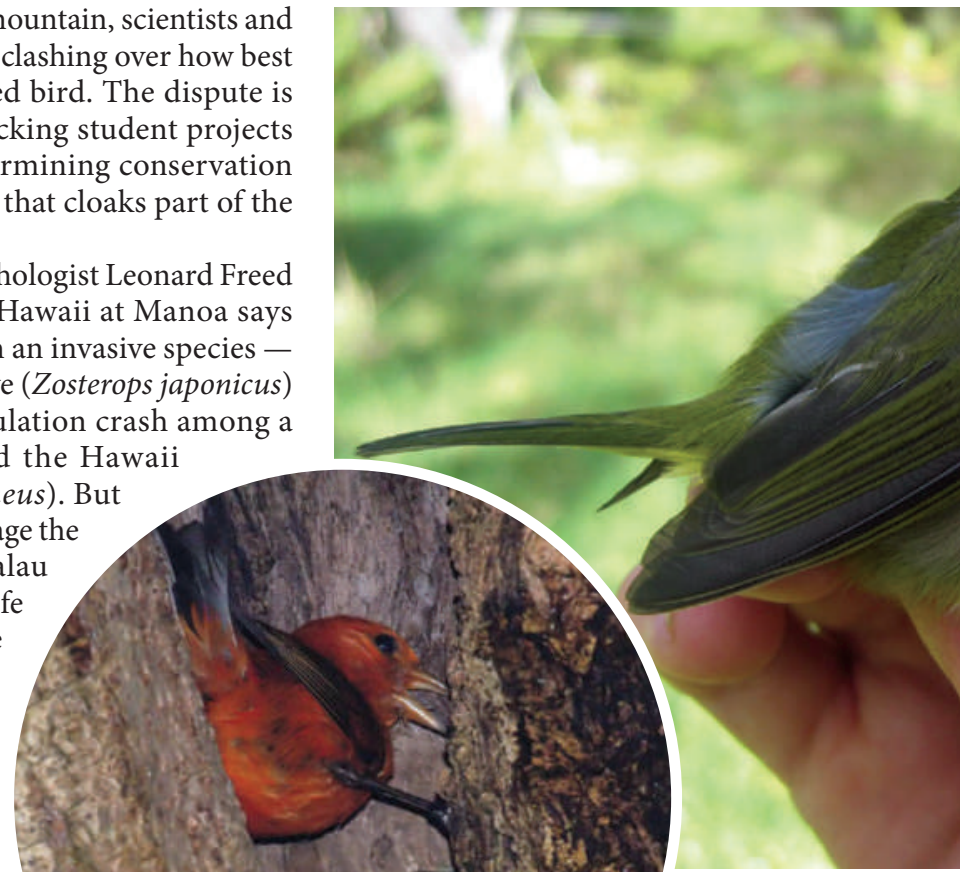

The Japanese white-eye (above) competes with the akepa (left) for food.

and even become extinct unless there is management intervention - which the refuge says is not needed. "We don't feel there is anything of major-league concern," says Jeffrey.

But in November, Freed and his colleagues published a study suggesting that the akepa population crashed in 2006 after five years of being "non-viable" (L. A. Freed et al. Evol. Ecol. Res. 10, 931-965; 2008). The team also argues that the Japanese white-eye competes with the akepa for food. Without the right nutrition, the akepa becomes prone to parasites such as chewing lice (L. A. Freed et al. J. Parasitology 94, 1009-1021; 2008). Freed estimates that there about 4,000 akepa in the refuge, and more than 20,000 Japanese white-eye. Jeffrey says he has not read Freed's published paper.

Michael Rosenzweig, editor-in-chief of Evolutionary Ecology Research, says the work is a classic example of one species forcing another out of an ecosystem. He calls

\section{Rule change for human grants sparks spat at NIH}

\section{BETHESDA, MARYLAND}

The US National Institutes of Health (NIH) is thinking of giving researchers who work with human subjects some space: 18 pages instead of 12 to set out their grant proposals.

The proposed change, presented on 5 December at a meeting of the NIH director's advisory committee, goes back on a suggestion made this spring by a panel overhauling the agency's peer-review system (see Nature 453, 835; 2008). The panel said then that it would cut all applications for major investigatorinitiated grants - R01 applications - from the current 25 pages to 12 , in an effort to streamline the system.

But at the advisory meeting, NIH acting deputy director Lawrence Tabak showed a slide declaring that "for R01 applications involving human subjects research, an additional 6 pages will be available for the research strategy section". Raynard Kington, acting director of the NIH, told the group that the change was made at the request of NIH staff who monitor grants. There were "very strong requests from programme staff that there be at least some option for additional information for clinical studies", he said.

Written applications involving humans can demand more detail, NIH staff say, because they need to explain how the researchers plan to deal with problems unique to humans, such as patients not taking medicines, the under-reporting of risk behaviours, and how studies are blinded and unblinded. Kington's committee of 15 advisers vehemently disgareed. On a straw vote, they unanimously 
the Freed paper "so important that it went through intense vetting".

Clashes between academics and conservation managers are not uncommon - but rarely do relations become quite so strained. Since 2006, Freed has not been granted permits to work in the reserve because of the ongoing disputes. When Freed asked graduate students to follow the birds instead, Richard Waas, the refuge manager at the time, demanded that they stop, saying they did not have the necessary permits. Refuge officials then threatened to call law-enforcement rangers.

\section{Blocked projects}

Dawn Reding, now a PhD candidate at Iowa State University in Ames, is one of several students who have been affected by the situation. She says that being refused permission for her akepa study in 2004 delayed her master's project by a year; "I was really upset," she says.

Matthew Medeiros, a native Hawaiian and undergraduate student, says that his proposal to use artificial nests to study akepa was rejected because of the conflict. "If you were associated with [Freed], Jeffrey blocked everything," says Medeiros, who is now a graduate student at the University of Missouri in St Louis.

Jeffrey says the student cases have been "blown out of proportion".

For years Freed and refuge officials also argued over how best to assess blood samples from akepa to test them for malaria. The fight dragged on for so long that key work was approved only after Freed's federal grant for the work had expired.

Gary Ostrander, the vice-chancellor for research at the University of Hawaii, says he hopes the university can "continue to work collectively" with the refuge.

Rex Dalton

opposed the proposal, arguing that it was prejudicial to basic scientists. "It's a terrible idea," said Thomas Kelly, director of the SloanKettering Institute in New York City. "It invites gaming the system. You check that [human subjects] box and get $50 \%$ more space."

Mary-Claire King, a geneticist at the University of Washington in Seattle, argued that applications involving human subjects do not require any more space than those for "flies, worms, mice, bacteria or yeast".

The decision of whether or not to implement the change ultimately rests with Kington, who says it will be made "pretty quickly". Whatever the outcome, the new rules won't come into effect until 2010.

Meredith Wadman

\section{Plant hormone study pulled}

Two years ago, three papers ${ }^{1-3}$ made a splash in the plant biology world by identifying protein receptors for abscisic acid (ABA), a key hormone in plant physiology. This week, Nature is retracting one of those papers ${ }^{1}$ after reports that the work could not be replicated. The two other papers still stand, although one $\mathrm{e}^{3}$ has been questioned by several researchers ${ }^{4-7}$.

The retraction is a setback in the search to find receptors for $\mathrm{ABA}$, a notoriously difficult task. ABA responds to environmental stresses such as drought, and is an alluring target for agricultural companies hoping to produce drought-resistant crops.

The retraction in Nature comes from the team that did the work, led by Robert Hill of the University of Manitoba in Winnipeg, Canada. Hill says the experiments were carried out by postdoc Fawzi Razem, who has since left the university; Hill says he does not know for where. A Nature reporter was unable to contact Razem.

John Danakas, director of public affairs for the university, says that he cannot comment on this case in particular, but says that "normally when there are problems with research results being reproducible, there would be an investigation at the senior administrative level".

According to the search tool Scopus, Hill's paper has been cited 120 times, and is the most highly cited study among the 95 results for 'abscisic acid receptor' in the past three years.

Hill says he moved on from the project after the paper was published, but started to realize something might be wrong after some of his postdocs returned to it in late 2007 and could not replicate the results. He was also contacted by Catherine Day of the University of Otago in Dunedin, New Zealand, who could not repeat the work either. "I suspect it has hurt a lot of people," he says. "It certainly hurt my lab quite significantly. I certainly feel very bad about it and am very apologetic to the community."

According to Hill, his team interpreted an experiment as showing that $\mathrm{ABA}$ broke up a binding interaction between the receptor candidate FCA, involved in flowering, and another protein, FY, because ABA bound better to FCA than did FY. In fact, he says, the FY protein was not properly prepared, and probably never bound to FCA at all. Another experiment purporting to show direct binding between FCA and ABA was miscalculated and, says Hill, "the assay procedure is also suspect".

Some plant-hormone specialists had wondered about the results of this and the other papers from the beginning, as they did not fit with the rest of what was known about ABA. The studies all used in vitro biochemical techniques to identify the receptor, rather than the more usual method of identifying and cloning mutated genes before determining if they coded for a receptor.

"There was nothing really wrong with the paper; you couldn't say 'this gel isn't any good', says Peter McCourt, an ABA specialist at the University of Toronto, Canada. But "none of it linked up with any of the genetics that had been done in the previous 20 years".

The other papers identify similarly unexpected receptors. "People who are doing this are sceptical and are not putting all their money on these findings," says Jianhua Zhang, who works on other aspects of ABA at Hong Kong Baptist University.

Dayblames the problems on tricky assays. "I think they've just had a bad start. These proteins are difficult to work with." McCourt thinks such experiments might be too complicated to pursue. Collecting proteins from plant cells for binding studies is easier said than done, he says, as plant cells are particularly crowded, complex places.

Meanwhile, Hill says, "I just want to get this behind me."

Emma Marris

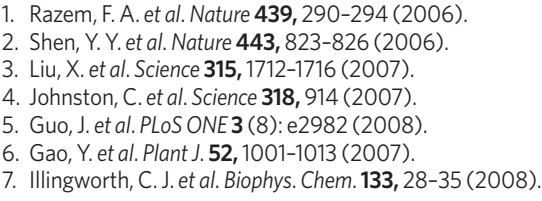

